\title{
Perancangan Sistem Sensor Pemonitor Lingkungan Berbasis Jaringan Sensor Nirkabel
}

Nurhuda Maulana $^{1)}$, Oky Dwi Nurhayati ${ }^{2}$, Eko Didik Widianto ${ }^{2)}$

Program Studi Sistem Komputer, Fakultas Teknik, Universitas Diponegoro

Jalan Prof. Soedarto, SH, Tembalang, Semarang, Indonesia

\begin{abstract}
Air pollution is a problem that get a lot of people's attention, especially at campus environment. It is evocate the stakeholder of campus to monitor the environmental conditions at the campus which themed a green campus. Advances in science and technology, especially in computer and embedded systems in principle can be applied to solve this problem. There are creating an application system that is equipped with sensor to monitor the air quality level wirelessly. The system supports several environmental monitoring sensors that are connected in a wireless sensor network. The objective of this research was to design and create a sensor system that can monitor environment condition quantity by providing the appropriate output value.
\end{abstract}

Sensors that used to read the air quality parameters is TGS 2600 to read the gas concentration of carbon monoxide (CO), TGS 2201 for nitrogen dioxide (NO2), GP2Y1010AUOF for particulate matter, BH1750 for light ambient, and SHT11 for humidity and temperature. This sensor system using Arduino board that based on Atmega 2560 microcontroller. This system is equipped with RTC as a time and GPS as a coordinate where the sensor system is placed as a node.

The result of this reseach is the system able to read parameters as air quality monitoring well. The error reading in this sensor system is $0.69 \mathrm{ppm} \mathrm{CO}$ gas, $2.8 \mathrm{~lx}$ on the intensity of light, $0.22 \mathrm{C}$ in temperature reading, and $0.98 \%$ in humidity readings.

Keywords : Wireless Sensor Network, Sensor, Atmega 2560, Arduino.

\section{PENDAHULUAN}

$\mathrm{P}$ encemaran udara akhir - akhir ini merupakan masalah yang banyak mendapat perhatian masyarakat, khususnya lingkungan kampus. Hal tersebut menggugah para pemangku kepentingan kampus untuk turut andil dalam memantau kondisi lingkungan kampus dengan mengangkat tema kampus hijau.

Pada kasus kampus hijau, diperlukan pemantauan terhadap kondisi lingkungan sekitar kampus. Kondisi lingkungan yang dipantau berupa parameter - parameter lingkungan seperti konsentrasi karbon monoksida (CO), nitrogen dioksida $\left(\mathrm{NO}_{2}\right)$, kepadatan partikel debu, intensitas cahaya, kelembaban udara dan suhu lingkungan. ${ }^{[1]}$

Kemajuan ilmu pengetahuan dan teknologi terutama di bidang elektronika dan instrumentasi, pada prinsipnya dapat diterapkan untuk mengatasi masalah tersebut, yaitu dengan membuat suatu sistem aplikasi yang dilengkapi dengan sensor untuk memantau tingkat kualitas udara secara nirkabel. Sistem ini mendukung beberapa sistem sensor pemantau lingkungan yang diletakkan di beberapa titik strategis pada lingkungan kampus. Dengan menggunakan komunikasi nirkabel, maka instalasi akan menjadi lebih mudah.

Penelitian terdahulu sebagai referensi penelitian ini yaitu dengan membuat sebuah sistem pada jaringan sensor nirkabel menggunakan sensor DHT11. Sensor ini mampu membaca suhu dan kelembaban, dengan memiliki akurasi yang kurang baik. ${ }^{[2]}$

Adapun tujuan yang akan dicapai pada Tugas Akhir ini adalah merancang sistem yang dilengkapi sensor untuk memantau kondisi lingkungan secara kuantitas dengan memberikan nilai keluaran yang sesuai dan membuat sistem aplikasi yang dapat memberikan nilai keluaran yang sesuai dengan lingkungan.

\section{METODE PENELITIAN}

Bagian bab ini membahas mengenai kebutuhan dan metode yang digunakan untuk pengembangan sebuah perancangan sistem meliputi identifikasi kebutuhan, perancangan perangkat keras, perangkat lunak serta implementasi dan pengujian dalam pembuatan sistem.

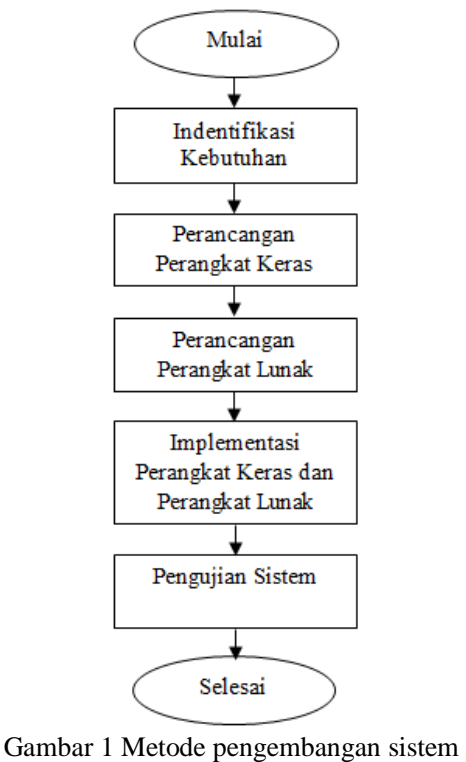

Metode pengembangan dimulai dengan identifikasi kebutuhan sistem. Pada tahap ini dijabarkan kebutuhan kebutuhan baik fungsional maupun non fungsional sistem. Tahap selanjutnya yaitu perancangan perangkat keras dan perangkat lunak berdasarkan kebutuhan sistem yang telah dibuat sebelumnya. Kemudian implementasi dan pengujian 
terhadap sistem yang telah dirancang. Pada tahap implementasi perangkat keras dilakukan dengan mendesain dan mencetak papan sirkuit cetak, sedangkan implementasi perangkat lunak dengan membuat program dan mengunduhnya ke papan Arduino Mega 2560. Pengujian sistem menjelaskan hasil pengujian berupa pengukuran pembacaan pada masing masing sensor dan komponen lainnya.

\section{PERANCANGAN SISTEM}

Pada bagian ini membahas tentang spesifikasi kebutuhan, perancangan perangkat keras, dan perancangan perangkat lunak.

A. Identifikasi Kebutuhan Sistem

Identifikasi kebutuhan sistem membahas tentang kebutuhan fungsional dan kebutuhan non fungsional.

Kebutuhan fungsional dalam perancangan sistem adalah sistem mampu melakukan monitoring terhadap keadaan lingkungan menggunakan sensor. Sistem mampu menampilkan hasil pembacaan sensor $\mathrm{NO}_{2}, \mathrm{CO}$, debu, intensitas cahaya, suhu dan kelembaban melalui komunikasi serial. Sistem mampu menampilkan pewaktu dari RTC berupa jam dan tanggal melalui komunikasi serial. Sistem mampu menampilkan koordinat posisi sistem berupa nilai derajat garis bujur dan garis lingkar bumi melalui komunikasi serial.

Kebutuhan non fungsional dalam perancangan sistem adalah sistem menggunakan mikrokontroler ATmega 2560 pada papan Arduino sebagai pusat kendali untuk membaca nilai keluaran sensor. Sistem dijalankan dengan catu daya sebesar $9 \mathrm{~V}$. Sistem berupa papan sirkuit cetak yang didesain untuk dapat dipasang dengan papan Arduino Mega 2560. Sistem menggunakan bahasa pemrograman $\mathrm{C}$ yang terapkan pada perangkat lunak aplikasi Arduino IDE.

\section{B. Perancangan Perangkat Keras}

Proses perancangan perangkat keras menjabarkan rancangan perangkat keras yang akan digunakan untuk membangun sistem, mulai dari perangkat keras utama yang dibutuhkan sistem hingga instrumen elektronika pendukungnya. Gambar 2 merupakan diagram blok perangkat keras sistem yang menunjukkan rancangan perangkat keras sistem.

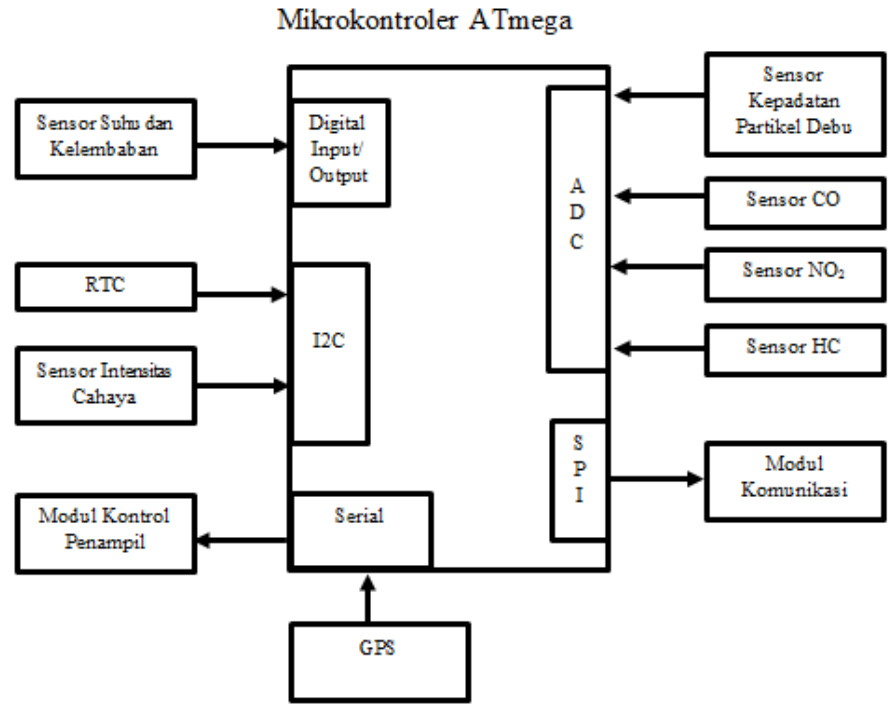

Gambar 2 Diagram blok sistem.

Pusat kendali sistem menggunakan mikrokontroler ATmega 2560 pada papan Arduino Mega 2560. Komponen yang terhubung dengan sistem diantaranya adalah GP2Y1010AU0F sebagai sensor kepadatan partikel debu, TGS 2600 sebagai sensor CO, TGS 2201 sebagai sensor $\mathrm{NO}_{2}$ dan HC, SHT11 sebagai sensor suhu dan kelembaban, BH1750 sebagai sensor intensitas cahaya, modul DS1307 sebagai RTC (Real Time Clock), dan penerima GPS GY-GPS6MV2 sebagai penerima koordinat GPS.

Sedangkan untuk modul kontrol penampil menggunakan Arduino Uno sebagai kendali penampil dot matrik p10 dan untuk modul komunikasi menggunakan modul radio nRF905. Tabel 1 menunjukkan antarmuka pin arduino dengan komponen pada sistem.

Tabel 1 Konfigurasi pin sistem

\begin{tabular}{|c|c|c|}
\hline No & $\begin{array}{l}\text { Antarmuka } \\
\text { Pin Arduino }\end{array}$ & Antarmuka Pin Komponen \\
\hline 1 & 2 & Modul Komunikasi \\
\hline 2 & 3 & Modul Komunikasi \\
\hline 3 & 4 & $\begin{array}{l}\text { LED Sensor Kepadatan Partikel } \\
\text { Debu }\end{array}$ \\
\hline 4 & 5 & SDA Sensor SHT11 \\
\hline 5 & 6 & SCL Sensor SHT11 \\
\hline 6 & 7 & Modul Komunikasi \\
\hline 7 & 8 & Modul Komunikasi \\
\hline 8 & 9 & Modul Komunikasi \\
\hline 9 & 14 (TX3) & Modul Kontrol Penampil \\
\hline 10 & $15(\mathrm{RX} 3)$ & Modul Kontrol Penampil \\
\hline 11 & $18(\mathrm{TX} 1)$ & RX GPS GY-GPS6MV2 \\
\hline 12 & $19(\mathrm{RX} 1)$ & TX GPS GY-GPS6MV2 \\
\hline 13 & 20 (SDA) & $\begin{array}{l}\text { SDA RTC, Modul Kontrol Penampil } \\
\text { dan Sensor BH1750 }\end{array}$ \\
\hline 14 & 21 (SCL) & $\begin{array}{l}\text { SCL RTC, Modul Kontrol Penampil } \\
\text { dan Sensor BH1750 }\end{array}$ \\
\hline 15 & 22 & DIP Switch \\
\hline 16 & 23 & DIP Switch \\
\hline 17 & 24 & DIP Switch \\
\hline 18 & 25 & DIP Switch \\
\hline 19 & 50 (MOSI) & Modul Komunikasi \\
\hline 20 & 51 (MISO) & Modul Komunikasi \\
\hline 21 & $52(\mathrm{SCK})$ & Modul Komunikasi \\
\hline 22 & 53 (SS) & Modul Komunikasi \\
\hline 23 & $\mathrm{~A} 0$ & Keluaran Sensor GP2Y1010AU0F \\
\hline 24 & A1 & Keluaran CO Sensor TGS2600 \\
\hline 25 & $\mathrm{~A} 2$ & Keluaran $\mathrm{NO}_{2}$ Sensor TGS2201 \\
\hline 26 & A3 & Keluaran HC Sensor TGS2201 \\
\hline
\end{tabular}

Sistem menggunakan beberapa pin yang tersedia pada papan Arduino Mega 2560. Diantaranya adalah empat pin keluaran analog dari sensor, dua pasang pin serial untuk penerima koordinat GPS dan modul kontrol penampil, $\mathrm{I}^{2} \mathrm{C}$ yaitu pin SDA dan pin SCL untuk modul RTC dan sensor intensitas cahaya, dan SPI yaitu pin MOSI, MISO, SCK, dan SS untuk modul komunikasi radio.

C. Perancangan Perangkat Lunak

Perangcangan perangkat lunak akan menjelaskan tahapan dalam pembuatan sistem berupa program yang mengendalikan 
perangkat keras. Sistem mampu membaca keadaan lingkungan dari keluaran sensor, membaca waktu sesuai dengan RTC yang terpasang, membaca koordinal lokasi sistem sesuai dengan penerima GPS, dan mampu menjadwalkan pembacaan sensor, pengiriman data dan menampilkan data pada penampil dot matrik. Gambar 3 merupakan diagram alir untuk perancangan program secara umum.

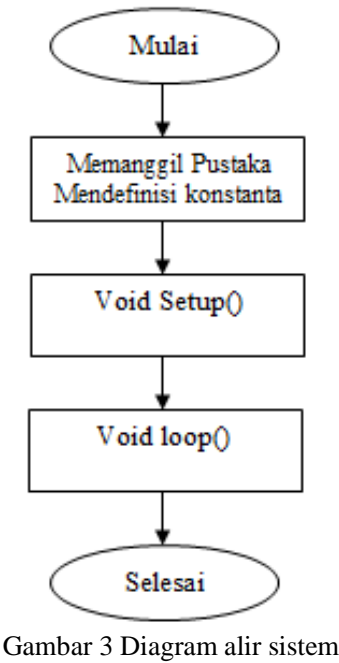

Pada Gambar 3 yang pertama dilakukan adalah pemanggilan pustaka yang dibutuhkan dalam program, yaitu pustaka komunikasi I2C, RTC, GPS, sensor intensitas cahaya, sensor suhu dan kelembaban. Selanjutnya adalah proses void setup(). Dalam proses ini, berisi tentang semua perintah dan inisialisasi yang dieksekusi secara tunggal atau hanya sekali. Proses terakhir adalah proses void $\operatorname{loop}()$, yang berisi tentang perintah - perintah yang akan dieksekusi secara berulang kali. Gambar 4 menjelaskan diagram alir untuk void setup().

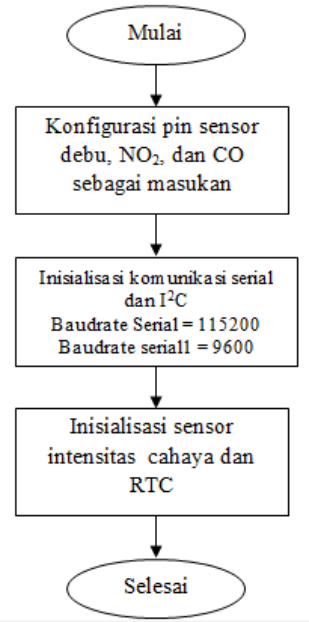

Gambar 4 Diagram alir void setup()

Pertama yang dieksekusi adalah perintah untuk konfigurasi sensor. Perintah ini berfungsi untuk mengkonfigurasi pin - pin yang digunakan oleh sensor pada mikrokontroler sehingga dapat terbaca oleh mikrokontroler. Selanjutnya adalah inisialisasi komunikasi serial dan I2C. Komunikasi serial digunakan untuk menghubungkan mikrokontroler dengan komputer menggunakan baudrate 115200. Selain dengan komputer, komunikasi serial juga digunakan oleh GPS dengan baudrate 9600. Baudrate merupakan kecepatan transmisi data serial dengan satuan bit per detik. Yang terakhir adalah inisialisasi sensor. Dalam inisialisasi ini, berfungsi untuk memulai fungsi kerja terhadap sensor - sensor yang membutuhkan fungsi sebagai inisialisasi awal. Gambar 5 merupakan diagram alir dari proses void $\operatorname{loop}()$.

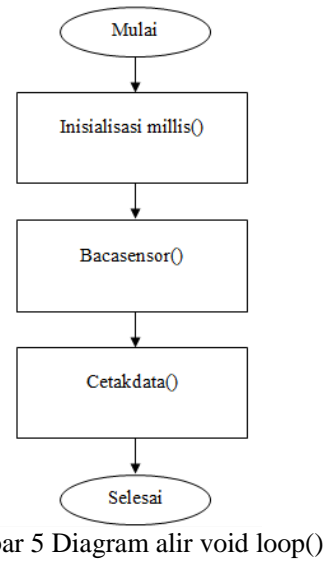

Pertama yang dieksekusi adalah memulai millis. Millis adalah pewaktu yang bekerja dengan mengembalikan nilai dalam mili detik dihitung sejak mikrokontroler menyala. Millis digunakan sebagai interupsi pewaktu yang akan menghitung pertambahan waktu dalam mili detik. Selanjutnya adalah mengeksekusi bacasensor() yang merupakan sintaks untuk memberikan pembagian penjadwalan pada sensor untuk membaca nilai perubahan yang terjadi di lingkungan. Yang terakhir adalah mengeksekusi cetakdata() sebagai sintaks yang digunakan untuk menggabungkan nilai keluaran dari setiap sensor dan mencetaknya dalam serial monitor. Gambar 6 menunjukkan diagram alir untuk pembacaan sensor.

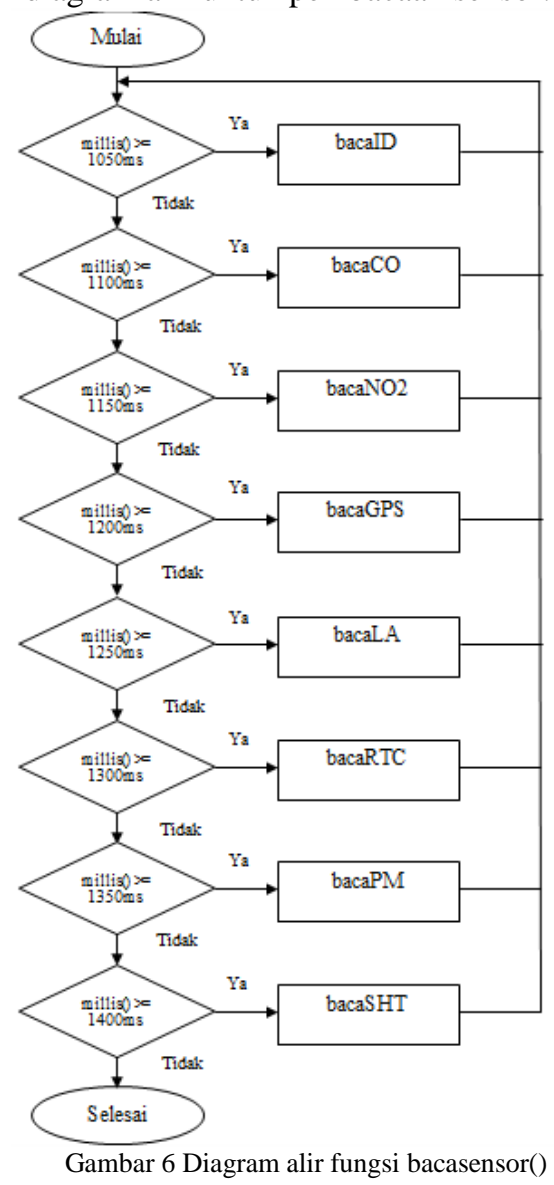

Setiap sensor diurutkan berdasarkan waktu lama satu kali pembacaan. Slot waktu antar sensor berkisar 50 mili detik. Gambar 7 menunjukkan diagram alir untuk mencetak data ke dalam serial monitor. 


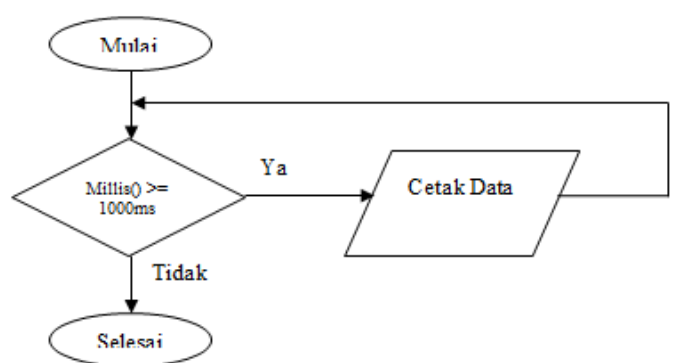

Gambar 7 Diagram alir fungsi cetakdata()

Data akan dicetak untuk setiap 1000 mili detik. Data tersebut merupakan kumpulan nilai pembacaan sensor - sensor beserta waktu dan lokasi dalam bentuk array dengan tipe data String.

\section{IMPLEMENTASI DAN PENGUJIAN SISTEM}

Implementasi sistem adalah hasil dari bagian perancangan perangkat keras dan perangkat lunak. Pengujian dilakukan untuk menguji sistem apakah mampu bekerja sesuai dengan hasil perancangan yang telah dibuat dengan memberikan perilaku - perilaku dan keluaran yang sesuai kebutuhan.

A. Implementasi Perangkat Keras dan Perangkat Lunak

Implementasi perangkat keras terdiri dari keseluruhan pembuatan perangkat keras sistem. Sistem ini menggunakan papan Arduino Mega 2560 sebagai pusat kontrol dari sistem. Terhubung dengan beberapa sensor yang berfungsi untuk memantau lingkungan seperti konsentrasi gas karbon monoksida (CO), gas nitrogen dioksida $\left(\mathrm{NO}_{2}\right)$, kepadatan partikel debu (PM), intensitas cahaya, suhu dan kelembaban lingkungan. Selain itu terdapat RTC sebagai pewaktu dan GPS sebagai penanda lokasi alat.

Perangkat yang diimplementasikan dalam sistem merupakan sebuah papan sirkuit cetak sebagai tempat komponen - komponen sistem saling terhubung untuk menjadi sebuah sistem perangkat keras yang dapat secara mudah dihubungkan dengan papan Arduino Mega 2560. Gambar 8 menunjukkan desain papan sirkuit cetak.

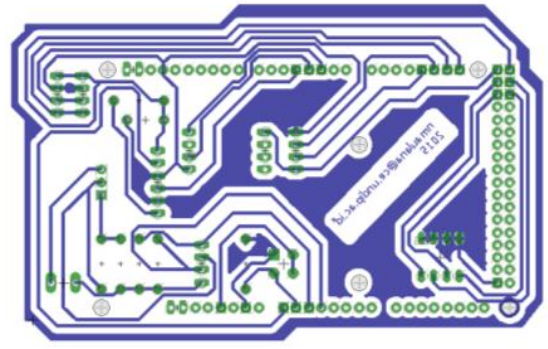

Gambar 8 Desain papan sirkuit cetak sistem

Desain ini kemudian dicetak pada papan sirkuit cetak dan dipasangkan dengan komponen - komponen sistem sesuai dengan perancangan sistem yang telah dibuat. Gambar 9 menunjukkan papan sirkuit sistem yang telah dibuat. Papan ini terhubung langsung dengan pin - pin yang ada pada papan Arduino Mega 2560.

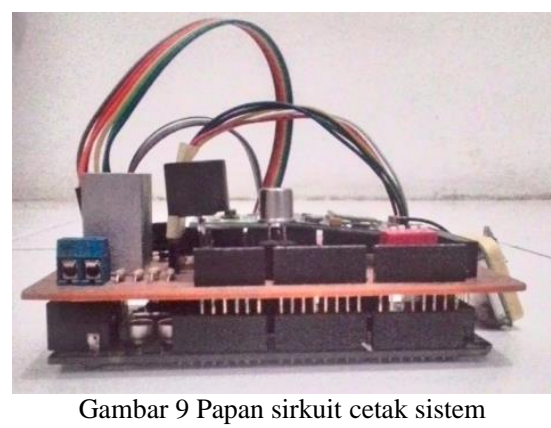

Papan ini juga memiliki kepala pin yang dapat menghubungkan pin - pin yang ada pada papan Arduino Mega 2560 dengan kontroler penampil dot matrik, modul komunikasi, dan komponen lainnya.

Implementasi perangkat lunak merupakan pembuatan program sistem sensor dengan menggunakan arduino yang berbasis bahasa $\mathrm{C}$. Implementasi perangkat lunak dilakukan dengan memprogram keseluruhan sistem sesuai dengan perancangan sebelumnya. Antara lain sistem penjadwalan pembacaan sensor, menampilkan data dan memprogram masing - masing sensor.

\section{B. Pengujian Sistem}

Pengujian sistem dilakukan dengan membaca nilai keluaran dari masing - masing sensor beserta perangkat lainnya, yaitu sensor TGS2201, sensor TGS2600, sensor GP2Y1010AU0F, sensor BH1750, sensor SHT11, RTC DS1307,dan GPS GY-GPS6MV2.

Pengujian sensor TGS2201 merupakan pengujian sistem untuk parameter konsentrasi gas $\mathrm{NO}_{2}$. Pengujian dilakukan dengan membandingkan nilai keluaran sensor dengan datasheet. Berdasarkan datasheet dapat diketahui karakteristik nilai keluaran yang dapat terukur. Tabel 2 menunjukkan karakteristik sensor TGS2201 berdasarkan datasheet.

Tabel 2 Karakteristik Sensor TGS2201 ${ }^{[3]}$

\begin{tabular}{|c|c|c|c|c|}
\hline No & Rs/Ro & $\mathrm{NO}_{2}(\mathrm{ppm})$ & $\mathrm{Vrl}(\mathrm{V})$ & $\mathrm{ADC}$ \\
\hline 1 & 1.5 & 0.1 & 1.70 & 349 \\
\hline 2 & 1.9 & 0.2 & 1.45 & 297 \\
\hline 3 & 2.5 & 0.3 & 1.19 & 243 \\
\hline 4 & 3.3 & 0.4 & 0.95 & 195 \\
\hline 5 & 4.3 & 0.5 & 0.77 & 157 \\
\hline 6 & 5.5 & 0.6 & 0.62 & 127 \\
\hline 7 & 6.8 & 0.7 & 0.51 & 105 \\
\hline 8 & 7.8 & 0.8 & 0.45 & 93 \\
\hline 9 & 9.1 & 0.9 & 0.39 & 81 \\
\hline 10 & 10.1 & 1 & 0.36 & 73 \\
\hline
\end{tabular}

Tabel 2 merupakan data yang didapat dari datasheet, sedangkan Vrl dan ADC didapatkan dari perhitungan Rs. ${ }^{[4]}$ Berdasarkan Tabel 2, didapatkan hasil pengujian sebanyak 10 kali dengan nilai konsentrasi gas yang berbeda. Tabel 3 menunjukkan hasil pengujian terhadap sensor TGS2201. 
Tabel 3 Hasil pengujian Sensor TGS2201

\begin{tabular}{|c|c|c|}
\hline No. & ADC & $\mathrm{NO}_{2}(\mathrm{ppm})$ \\
\hline 1 & 347 & 0.079 \\
\hline 2 & 336 & 0.155 \\
\hline 3 & 304 & 0.219 \\
\hline 4 & 277 & 0.273 \\
\hline 5 & 253 & 0.321 \\
\hline 6 & 205 & 0.417 \\
\hline 7 & 189 & 0.449 \\
\hline 8 & 173 & 0.481 \\
\hline 9 & 134 & 0.571 \\
\hline 10 & 114 & 0.651 \\
\hline
\end{tabular}

Bedasarkan tabel 2 dan Tabel 3, maka dapat diketahui perbandingan nilai yang didapatkan berdasarkan datasheet dengan yang terukur pada sensor. Gambar 10 merupakan perbandingan nilai pada datasheet dan nilai yang terukur pada sensor menggunakan grafik.

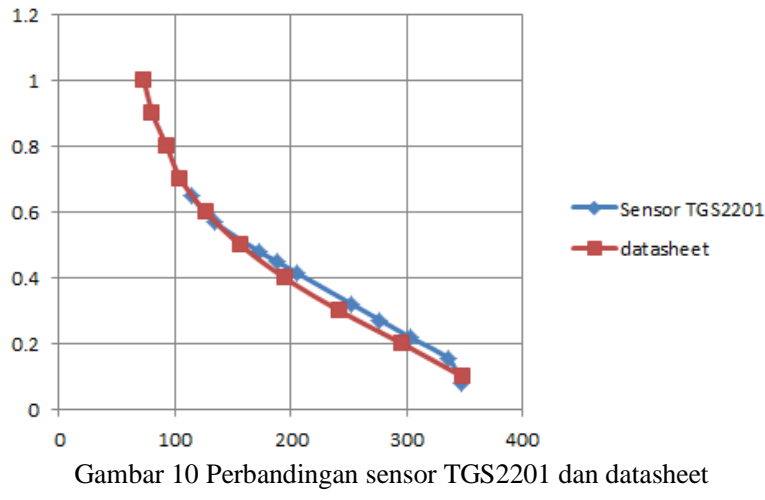

Berdasarkan Gambar 10, hasil pengujian yang dapat terukur sensor hanya mencapai kurang dari 0.7 ppm, sedangkan pada datasheet data yang dapat terukur sampai 1 ppm. Hal ini dikarenakan kondisi saat pengujian, konsentrasi gas $\mathrm{NO}_{2}$ yang ada terbaca tidak mencapai $1 \mathrm{ppm}$.

Pengujian sensor TGS2600 merupakan pengujian untuk parameter konsentrasi gas CO. Pengujian dilakukan dengan membandingkan nilai keluaran sensor dengan alat ukur berupa $\mathrm{CO}$ meter dari Extech Instrument.

Pengujian dilakukan selama 15 kali pembacaan dengan menggunakan asap sebagai polutan gas CO. Tabel 4 menunjukkan hasil pembacaan gas $\mathrm{CO}$ yang terbaca oleh sensor dan alat ukur.

Tabel 4 Hasil pengujian sensor TGS2600

\begin{tabular}{|c|c|c|c|}
\hline No. & $\begin{array}{c}\text { TGS2600 } \\
(\mathrm{ppm})\end{array}$ & $\begin{array}{c}\text { CO Meter } \\
(\mathrm{ppm})\end{array}$ & Selisih \\
\hline 1 & 0.00 & 0 & 0.00 \\
\hline 2 & 1.82 & 1 & 0.82 \\
\hline 3 & 2.69 & 2 & 0.69 \\
\hline 4 & 3.57 & 3 & 0.57 \\
\hline 5 & 4.57 & 4 & 0.57 \\
\hline 6 & 5.44 & 5 & 0.44 \\
\hline 7 & 6.32 & 6 & 0.32 \\
\hline 8 & 7.32 & 7 & 0.32 \\
\hline
\end{tabular}

\begin{tabular}{|c|c|c|c|}
9 & 8.19 & 8 & 0.19 \\
\hline 10 & 9.07 & 9 & 0.07 \\
\hline 11 & 10.07 & 10 & 0.07 \\
\hline 12 & 11.92 & 11 & 0.92 \\
\hline 13 & 19.82 & 18 & 1.82 \\
\hline 14 & 20.90 & 20 & 0.90 \\
\hline 15 & 32.74 & 30 & 2.74 \\
\hline \multicolumn{3}{|c|}{ Rata - rata } & 0.6952 \\
\hline
\end{tabular}

Berdasarkan Tabel 4 dapat dijelaskan bahwa rata - rata selisih nilai CO dari sensor dan CO meter yaitu sebesar 0.69. Dengan demikian, pembacaan konsentrasi gas CO dalam sistem ini berfungsi dengan baik. Gambar 11 menunjukkan grafik perbandingan data yang terbaca oleh sensor dengan alat ukur berdasarkan hasil pengujian.

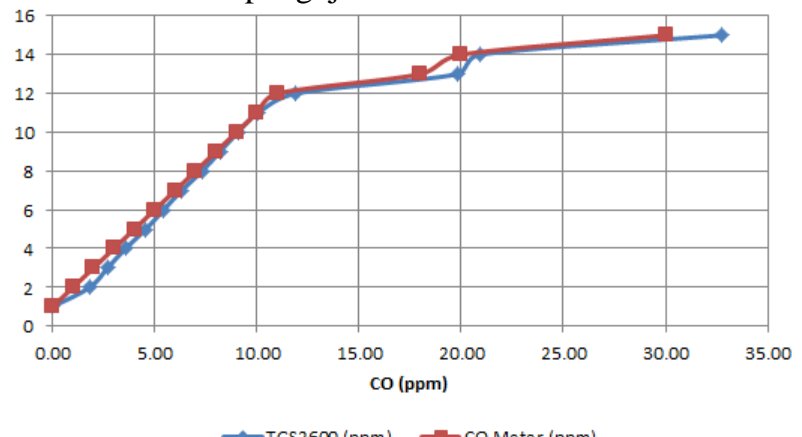

Gambar 11 Perbandingan sensor TGS2600 dan CO Meter

Sensor GP2Y1010AU0F merupakan sensor yang digunakan untuk mengukur kepadatan partikel debu di udara. Sensor ini mampu mengukur partikel debu dari $0 \mu \mathrm{g} / \mathrm{m} 3$ sampai kurang dari $1000 \mu \mathrm{g} / \mathrm{m} 3$. Pengujian sensor ini dilakukan dengan mengukur nilai tegangan dan partikel debu yang terbaca pada sensor, kemudian dibandingkan dengan datasheet sensor. Berdasarkan datasheet dari sensor GP2Y1010AU0F, dapat diketahui karakteristik sensor sesuai nilai tegangan keluaran dan partikel debu yang dapat terukur. Tabel 5 menunjukkan karakteristik sensor berdasarkan datasheet.

Tabel 5 Karakteristik sensor GP2Y1010AU0F $\mathrm{F}^{[5]}$

\begin{tabular}{|c|c|c|}
\hline No. & Tegangan $(\mathrm{v})$ & Nilai $\left(\mu \mathrm{g} / \mathrm{m}^{3}\right)$ \\
\hline 1 & 0.59 & 0 \\
\hline 2 & 1.15 & 100 \\
\hline 3 & 1.71 & 200 \\
\hline 4 & 2.29 & 300 \\
\hline 5 & 2.97 & 400 \\
\hline 6 & 3.53 & 500 \\
\hline 7 & 3.65 & 600 \\
\hline 8 & 3.67 & 700 \\
\hline 9 & 3.68 & 800 \\
\hline
\end{tabular}

Pengujian dilakukan sebanyak 15 kali pembacaan sensor. Untuk setiap kali pembacaan digunakan asap dengan konsentrasi yang berbeda sebagai sumber partikel debu. Tabel 6 merupakan hasil pengujian dari sensor terhadap nilai tegangan keluaran dan partikel debu yang terukur.

Tabel 6 Hasil pengujian sensor GP2Y1010AU0F 


\begin{tabular}{|c|c|c|}
\hline No. & Tegangan $(\mathrm{v})$ & Nilai $\left(\mu \mathrm{g} / \mathrm{m}^{3}\right)$ \\
\hline 1 & 0.63 & 6.78 \\
\hline 2 & 0.74 & 25.88 \\
\hline 3 & 0.89 & 50.79 \\
\hline 4 & 1.03 & 74.88 \\
\hline 5 & 1.18 & 100.62 \\
\hline 6 & 1.46 & 147.12 \\
\hline 7 & 1.75 & 196.95 \\
\hline 8 & 2.01 & 241.79 \\
\hline 9 & 2.2 & 274.17 \\
\hline 10 & 2.71 & 361.37 \\
\hline 11 & 2.95 & 402.02 \\
\hline 12 & 3.21 & 445.29 \\
\hline 13 & 3.4 & 478.46 \\
\hline 14 & 3.62 & 676.33 \\
\hline 15 & 3.76 & 969.3 \\
\hline
\end{tabular}

Berdasarkan Tabel 5 dan Tabel 6, maka dapat diketahui perbandingan nilai yang ada pada datasheet dengan nilai yang terukur pada sensor. Gambar 12 menunjukkan grafik perbandingan data yang terbaca oleh sensor dengan alat ukur berdasarkan hasil pengujian.

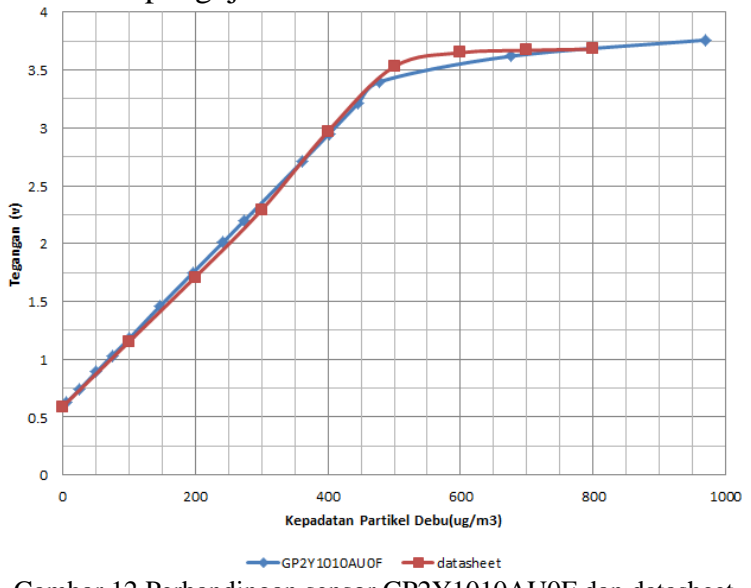

Gambar 12 Perbandingan sensor GP2Y1010AU0F dan datasheet

Berdasarkan Gambar 12, sensor mempunyai pengukuran yang baik dari $0 \mu \mathrm{g} / \mathrm{m} 3$ sampai $500 \mu \mathrm{g} / \mathrm{m} 3$. Dan untuk pengukuran diatas $500 \mu \mathrm{g} / \mathrm{m} 3$, pengukuran sensor akan menjadi kurang baik. Hal ini sesuai dengan karakteristik sensor pada datasheet, bahwa kenaikan nilai tegangan yang dihasilkan sensor akan sangat berpengaruh lebih besar pada kenaikan partikel debu yang terukur. Sehingga pembacaan sensor akan mengurangi keakuratan data.

Pengujian selanjutnya merupakan sensor BH1750FVI. Sensor ini merupakan sensor intensitas cahaya. Pengujian dilakukan dengan membandingkan nilai keluaran sensor dengan light meter yang terdapat pada alat ukur multi fungsi Krisbow KW06-291. Alat ini mempunyai rentang pembacaan 0 sampai 20000 lux.

Pengujian dilakukan sebanyak 15 kali pembacaan dengan menggunakan senter led putih sebagai sumber cahaya. Sensor dan alat ukur pembanding diletakkan berdekatan, sehingga akan mengurangi selisih pembacaan yang terlalu besar. Tabel 7 menunjukkan hasil pengujian dari sensor sebagai data terukur dan alat ukur pembanding terhadap perubahan intensitas cahaya. Tabel 7 menunjukkan hasil pengujian sensor BH1750.

Tabel 7 Hasil pengujian sensor BH1750

\begin{tabular}{|c|c|c|c|}
\hline No. & $\begin{array}{c}\text { Data Terukur } \\
(\operatorname{lux})\end{array}$ & $\begin{array}{c}\text { Data } \\
\text { Pembanding } \\
\text { (lux) }\end{array}$ & Selisih \\
\hline 1 & 0 & 0 & 0 \\
\hline 2 & 5 & 5 & 0 \\
\hline 3 & 14 & 15 & 1 \\
\hline 4 & 16 & 16 & 0 \\
\hline 5 & 25 & 26 & 1 \\
\hline 6 & 35 & 34 & 1 \\
\hline 7 & 39 & 40 & 1 \\
\hline 8 & 63 & 63 & 0 \\
\hline 9 & 86 & 85 & 1 \\
\hline 10 & 97 & 98 & 1 \\
\hline 11 & 132 & 134 & 2 \\
\hline 12 & 370 & 363 & 7 \\
\hline 13 & 472 & 485 & 13 \\
\hline 14 & 788 & 796 & 8 \\
\hline 15 & 887 & 881 & 6 \\
\hline \multicolumn{3}{|c|}{ Rata-rata } & 2.8 \\
\hline
\end{tabular}

Berdasarkan Tabel 7 dapat dilihat pembacaan nilai intensitas cahaya yang dapat ditangkap oleh sensor dan alat pembanding. Pada pengujian kali ini, didapatkan akurasi berdasarkan perbandingan nilai pembacaan sensor dengan alat ukur yaitu sebesar 0.10 kali dari pembacaan sensor sensor. Perbedaan pembacaan ini sesuai dengan datasheet sensor yang memiliki akurasi pembacaan berkisar 0.96 sampai 1.44 kali. Dari data tersebut, dapat diketahui besar kesalahan pembacaan sensor adalah 2,8 lux. Kesalahan pembacaan ini akan semakin besar jika sensor membaca nilai intensitas cahaya yang lebih besar dari nilai yang telah didapatkan dalam pengujian. Gambar 13 menunjukkan grafik perbandingan data yang terukur oleh sensor dengan alat ukur pembanding berdasarkan hasil pengujian.

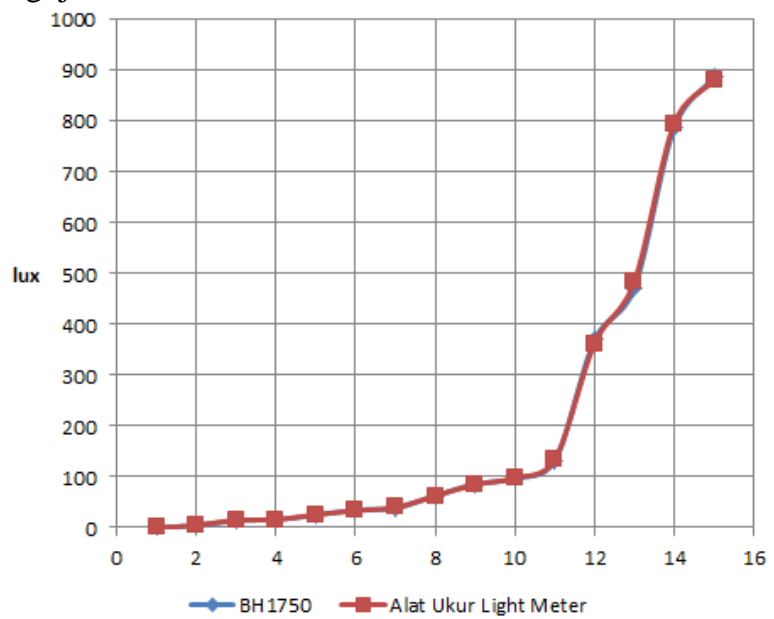

Gambar 13 Perbandingan sensor BH1750 dan Light Meter

Sensor SHT11 merupakan sensor yang digunakan untuk mengukur perubahan suhu dan kelembaban. Pengujian sensor ini dilakukan dengan membandingkan nilai keluaran sensor 
dengan suhu dan kelembaban dari alat ukur multi fungsi Krisbow KW06-291.

Pengujian dilakukan sebanyak 10 kali pembacaan. Sensor dan alat ukur pembanding diletakkan berdekatan. Tabel 8 merupakan hasil pengujian dari sensor dan alat ukur pembanding terhadap perubahan suhu dan kelembaban.

Tabel 8 Hasil pengujian sensor SHT11

Tabel 8 Hasil pengujian sensor SHT11
\begin{tabular}{|c|c|c|c|c|c|c|}
\hline \multirow{2}{*}{ No } & \multicolumn{2}{|c|}{ Sensor SHT11 } & \multicolumn{2}{c|}{ Alat Pembanding } & \multicolumn{2}{c|}{ Selisih } \\
\cline { 2 - 7 } & $\begin{array}{c}\text { Suhu } \\
\left({ }^{\circ} \mathrm{C}\right)\end{array}$ & $\begin{array}{c}\text { Kelembaba } \\
\mathrm{n}(\%)\end{array}$ & $\begin{array}{c}\text { Suhu } \\
\left({ }^{\circ} \mathrm{C}\right)\end{array}$ & $\begin{array}{c}\text { Kelembaba } \\
\mathrm{n}(\%)\end{array}$ & $\begin{array}{c}\text { Suhu } \\
\left({ }^{\circ} \mathrm{C}\right)\end{array}$ & $\begin{array}{c}\text { Kelembaba } \\
\mathrm{n}(\%)\end{array}$ \\
\hline 1 & 29.52 & 66.69 & 29.7 & 67.1 & 0.18 & 0.41 \\
\hline 2 & 30.19 & 64.47 & 30.5 & 65.1 & 0.31 & 0.63 \\
\hline 3 & 30.48 & 62.52 & 30.6 & 64.4 & 0.12 & 1.88 \\
\hline 4 & 30.73 & 64.83 & 31.2 & 65.1 & 0.47 & 0.27 \\
\hline 5 & 30.98 & 64.50 & 31.4 & 65.5 & 0.42 & 1.00 \\
\hline 6 & 31.50 & 64.21 & 31.7 & 64.2 & 0.20 & 0.01 \\
\hline 7 & 32.15 & 57.60 & 32.2 & 56.2 & 0.05 & 1.40 \\
\hline 8 & 32.27 & 58.80 & 32.4 & 57.2 & 0.13 & 1.60 \\
\hline 9 & 32.84 & 59.82 & 32.9 & 59.6 & 0.06 & 0.22 \\
\hline 10 & 33.11 & 55.41 & 33.4 & 57.8 & 0.29 & 2.39 \\
\hline \multicolumn{7}{|c|}{ Rata-rata } \\
\hline
\end{tabular}

Berdasarkan Tabel 8, didapatkan rata - rata kesalahan pembacaan suhu antara sensor SHT11 dengan alat ukur pembanding adalah $0.22{ }^{\circ} \mathrm{C}$. Sedangkan rata - rata kesalahan pembacaan kelembaban adalah $0.98 \%$. Kesalahan pembacaan pada suhu dan kelembaban sudah sesuai dengan datasheet sensor yang memiliki akurasi pembacaan sebesar $0.5{ }^{\circ} \mathrm{C}$ untuk suhu dan 3.5\% untuk kelembaban. Gambar 14 dan Gambar 15 menunjukkan grafik perbandingan suhu dan kelembaban yang terbaca oleh sensor dengan alat ukur pembanding berdasarkan hasil pengujian.

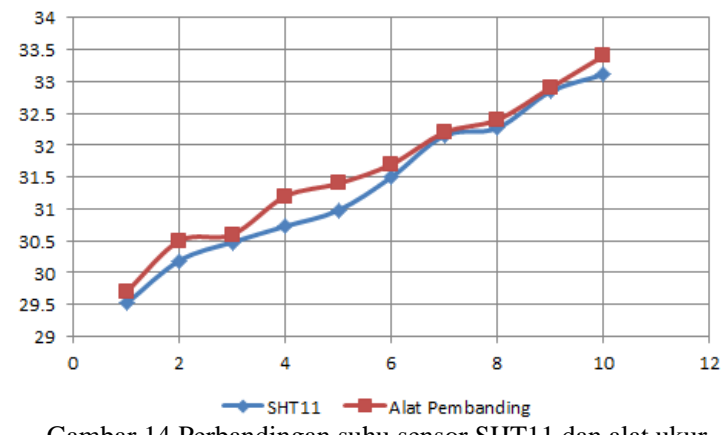

Gambar 14 Perbandingan suhu sensor SHT11 dan alat ukur

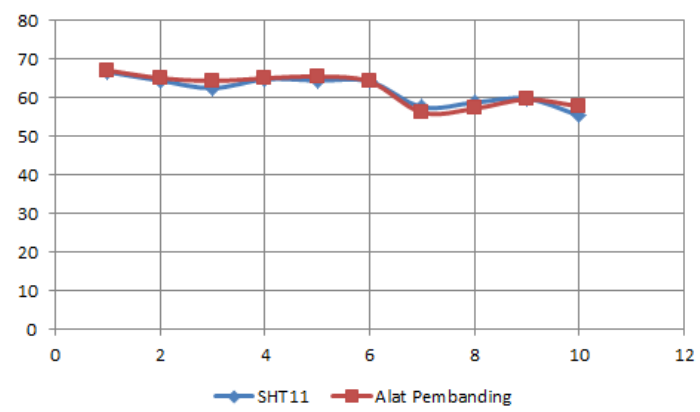

Gambar 15 Perbandingan kelembaban sensor SHT11 dan alat ukur
RTC DS1307 digunakan sebagai pewaktu dalam sistem. Pengujian dilakukan dengan membandingkan pembacaan waktu pada RTC DS1307 dengan waktu pada laptop. Tabel 9 menunjukkan hasil pengujian untuk pembacaan waktu pada RTC DS1307 dengan laptop.

Tabel 9 Hasil pengujian RTC DS1307

\begin{tabular}{|c|c|c|c|c|c|}
\hline \multirow{2}{*}{ No } & \multicolumn{2}{|c|}{ RTC DS1307 } & \multicolumn{2}{c|}{ Laptop } & \multirow{2}{*}{$\Delta t$} \\
\cline { 2 - 5 } & Tanggal & Jam & Tanggal & Jam & \\
\hline 1 & $20 / 12 / 2015$ & $23: 30: 01$ & $20 / 12 / 2015$ & $23: 30: 20$ & 19 \\
\hline 2 & $20 / 12 / 2015$ & $23: 30: 05$ & $20 / 12 / 2015$ & $23: 30: 24$ & 19 \\
\hline 3 & $20 / 12 / 2015$ & $23: 30: 10$ & $20 / 12 / 2015$ & $23: 30: 29$ & 19 \\
\hline 4 & $20 / 12 / 2015$ & $23: 30: 30$ & $20 / 12 / 2015$ & $23: 30: 49$ & 19 \\
\hline 5 & $20 / 12 / 2015$ & $23: 31: 00$ & $20 / 12 / 2015$ & $23: 31: 19$ & 19 \\
\hline 6 & $20 / 12 / 2015$ & $23: 40: 00$ & $20 / 12 / 2015$ & $23: 40: 19$ & 19 \\
\hline 7 & $20 / 12 / 2015$ & $23: 50: 00$ & $20 / 12 / 2015$ & $23: 50: 19$ & 19 \\
\hline 8 & $21 / 12 / 2015$ & $1: 00: 00$ & $21 / 12 / 2015$ & $1: 00: 19$ & 19 \\
\hline 9 & $21 / 12 / 2015$ & $2: 08: 23$ & $21 / 12 / 2015$ & $2: 08: 42$ & 19 \\
\hline 10 & $22 / 12 / 2015$ & $0: 00: 00$ & $22 / 12 / 2015$ & $0: 00: 19$ & 19 \\
\hline & & \multicolumn{2}{|c|}{ Rata - rata } & & 19 \\
\hline
\end{tabular}

Berdasarkan Tabel 9 diketahui terdapat perbedaan pengaturan pewaktuan awal, yaitu waktu pada RTC pukul 23:30:01 dan waktu pada laptop pukul 23:30:20 dengan $\Delta \mathrm{t} 0=$ 19 detik. Kesalahan pembacaan dalam pengujian selama 2 hari adalah jumlah rata - rata $\Delta \mathrm{t}-\Delta \mathrm{t} 0=0$. Dari hasil tersebut menunjukkan bahwa waktu pada RTC DS1307 tidak mengalami pergeseran waktu.

GPS NEO-6M merupakan modul penerima koordinat lokasi berdasarkan GPS. Pengujian dilakukan dengan membandingkan nilai keluaran modul GPS dengan GPS pada telepon pintar ASUS Zenfon 4C. Modul GPS diletakkan berdekatan dengan telepon pintar. Tabel 10 menunjukkan hasil pengujian modul GPS.

Tabel 10 Hasil Pengujian GPS GY-GPS6MV2

\begin{tabular}{|c|c|c|c|c|c|}
\hline \multirow{2}{*}{ No } & \multicolumn{2}{|c|}{ GPS GY-GPS6MV2 } & \multicolumn{2}{|c|}{ ASUS Zenfone 4C } & \multirow{2}{*}{$\begin{array}{c}\text { Selisih } \\
\text { (m) }\end{array}$} \\
\hline & Lintang & Bujur & Lintang & Bujur & \\
\hline 1 & -7.049743 & 110.42345 & -7.049721 & 110.423361 & 10.11 \\
\hline 2 & -6.974618 & 109.12685 & -6.974602 & 109.12687 & 2.35 \\
\hline 3 & -7.050756 & 110.44021 & -7.0509072 & 110.440325 & 20.87 \\
\hline & \multicolumn{4}{|c|}{ Rata-rata } & 11.11 \\
\hline
\end{tabular}

Selisih pengukuran didapatkan dengan menggunakan bantuan aplikasi Google Maps. Dengan cara menentukan jarak yang diukur berdasarkan koordinat garis bujur dan garis lintang pada GPS GY-GPS6MV2 dengan GPS pada ASUS Zenfon 4C. Berdasarkan Tabel 10, hasil pembacaan GPS NEO-6M dengan GPS ASUS Zenfon 4C memiliki selisih yang cukup kecil, yaitu dengan rata - rata sebesar 11,11 meter. 


\section{PENUTUP}

A. Kesimpulan

Berdasarkan hasil pengujian yang dilakukan terhadap sistem aplikasi yang dilengkapi dengan sensor untuk memantau kualitas lingkungan pada jaringan nirkabel, maka dapat disimpulkan sistem ini mampu membaca beberapa parameter - parameter sebagai pemantau kualitas lingkungan udara sekitar seperti konsentrasi gas nitrogen dioksida $\left(\mathrm{NO}_{2}\right)$, karbon monoksida (CO), kepadatan partikel debu, intensitas cahaya, suhu dan kelembaban relatif. Sistem ini dilengkapi dengan RTC sebagai pewaktu dan GPS sebagai koordinat lokasi dimana sistem sensor pada jaringan sensor nirkabel ditempatkan sebagai sebuah node. Waktu pembacaan sistem sensor ini dikerjakan setiap 1 detik, dengan slot waktu pembacaan setiap sensor selama 50 mili detik. Penjadwalan setiap sensor diurutkan berdasarkan lama waktu sensor dalam satu waktu untuk menghasilkan nilai keluaran.

Sensor TGS2600 mampu membaca konsentrasi gas CO dengan baik, dengan rentang pembacaan sekitar 0 ppm sampai $100 \mathrm{ppm}$. Pembacaan kesalahan untuk sensor ini sebesar 0,69 ppm. Sensor GP2Y1010AU0F mempunyai pengukuran yang baik dalam membaca kepadatan partikel debu sebesar $0 \mu \mathrm{g} / \mathrm{m}^{3}$ sampai $500 \mu \mathrm{g} / \mathrm{m}^{3}$. Sedangkan untuk pengukuran diatas 500 $\mu \mathrm{g} / \mathrm{m}^{3}$, pengukuran sensor akan menjadi kurang baik. Sensor BH1750 mampu membaca intensitas cahaya dengan kesalahan pembacaan sebesar 2.8 lux atau 0,1 kali lebih besar dari alat ukur pada pengujian dengan nilai 0 lux sampai kurang dari 900 lux. Sensor SHT11 mempunyai pengukuran yang baik dalam membaca suhu dan kelembaban relatif dari lingkungan. Kesalahan pembacaan berdasarkan pengujian untuk suhu sebesar $0,22{ }^{\circ} \mathrm{C}$, dan untuk kesalahan pembacaan kelembaban relatif sebesar 0,98 \% dari alat ukur. RTC DS1307 tidak mengalami pergeseran waktu dengan kesalahan pembacaan sebesar 0 detik dalam pengujian selama 2 hari.
B. Saran

Berdasarkan hasil pengujian yang dilakukan terhadap sistem aplikasi yang dilengkapi dengan sensor untuk memantau kualitas lingkungan pada jaringan nirkabel, dapat diberikan beberapa saran untuk pengembangan yang dapat dilakukan pada tugas akhir ini adalah sistem ini dapat dikembangkan sebagai sistem sensor pada portal sistem informasi lingkungan kota, seperti Smart City Jakarta dan Bandung. Desain papan sirkuit cetak dapat dikembangkan lebih baik dengan menambahkan rangkaian - rangkaian pengaman yang berfungsi sebagai pelindung sensor dari kerusakan akibat arus dan daya yang tidak sesuai kebutuhan sensor.

\section{DAFTAR PUSTAKA}

[1] Raharjo, Murshid., Dampak Pencemaran Udara pada Lingkungan dan Kesehatan Manusia, Magister Ilmu Lingkungan Universitas Diponegoro, Semarang, 2009.

[2] D. I. Af'idah, A. F. Rochim, dan E. D. Widianto, "Peran cangan Jaringan Sensor Nirkabel (JSN) untuk Memantau Suhu dan Kelembaban Menggunakan nRF24L01+," Jur nal Teknologi dan Sistem Komputer, vol. 2, no. 4, 2014

[3] Fikri, Yulfiani., Sistem Monitoring Kualitas Udara Berbasis Mikrokontroler ATmega8535 dengan Komunikasi Protokol TCP/IP, TRANSIENT, Vol. 2, No. 3, 2011.

[4] --, TGS 2201 - for detection of Gasoline and Diesel Exhaust Gas, http://www.datasheetarchive.com/ dlmain/Datasheets-11/DSA-218248.pdf, Diakses: 27 April 2015.

[5] --, GP2Y1010AU0F, https://www.sparkfun.com/ datasheets/Sensors/gp2y1010au_e.pdf , Diakses: 20 Maret 2015. 